\title{
Historical Perspectives on Regional Income Inequality in Brazil, 1872-2000
}

\author{
Eustáquio Reis
}

\section{Introduction}

Brazil is one of the most unequal societies in contemporary world. From 1960 to 2000 , the Gini coefficients of income per capita distribution remained practically constant around 0.6, one of the highest levels recorded at national level (Ipeadata 2014). In broad historical perspective, both institutional and geographic factors played fundamental roles in the generation and reproduction of Brazilian inequality in space and time. Slavery has had and still has overwhelming implications for social equity. Concentration of income and wealth and the low levels of education prevailing today are, to a large extent, her legacies. Needless to say, this is not an excuse for the ostensible lack of social concerns of government policies during most of the twentieth century.

Geographic factors were also decisive for spatial inequality. The continental size and the geographic heterogeneity of the country compounded with very high transport costs to create wide spatial disparities in the levels of productivity and income per capita. According to our estimates, The Gini coefficient of the distribution of municipal GDP per capita was above 0.45 in 1872 and remained above 0.4 from 1940 to 1980 when it started declining to reach 0.3 in 2000. Moreover, Theil decomposition exercises show that the contribution of the interregional component

\footnotetext{
A first version of this paper was prepared while the author was as Visiting Fellow to the project desiguALdades.net at the Freie Universität Berlin, in 2013. Preliminary versions were presented at IPEA, the Department of History of UCLA, the Spatial Economics Association Meeting, and the Harvard-Brazil Seminar. The author gratefully acknowledges hospitality and financial support from IPEA, CNPq and FAPERJ/PRONEX to the Project Nemesis-Proc. E52 168.171/2006 http://www.nemesis.org.br"www.nemesis.org.br); and to desiguALdades.network. He is also grateful for the comments from Jeffrey Williamson and Luis Bertola and the computer assistance and data compilation of Márcia Pimentel, Ana Isabel Alvarenga, and Maria do Carmo Horta.

E. Reis $(\square)$

IPEA, Rio de Janeiro, Brazil

e-mail: ejreis1@gmail.com
} 
to inequality of municipal GDP per capita increased systematically from $20 \%$ in 1872 to almost 50\% in 2000 (Barros et al. 1995; Azzoni 1997, 1999; Azzoni et al. 2000).

The historical roots of regional disparities are widely discussed in the Brazilian literature (Bértola et al. 2006; Buescu 1979; Cano 1993, 1997; Castro 1969; Denslow 1977; Furtado 1968, 1970; Leff 1972, 1973, 1991; Marcondes 2005). The discussion, however, lacks an adequate empirical basis. Statistical evidence when available is restricted to sparse data at state or macro-regional level. The sharp economic differences inside Brazilian states are completely neglected.

The chapter provides historical perspectives on spatial economic inequalities in Brazil. For this purpose it analyzes the spatial patterns of Brazilian economic growth making use of a database on Brazilian municipalities from 1872 to 2000. The first section offers a succinct account of the geographic forces shaping the secular development of the Brazilian economy highlighting the evolution of transport costs. The second section uses a series of maps to describe the spatial progression of income per capita and labor productivity from 1872 to 2000 . In a more rigorous fashion, the third section estimates econometric models of growth convergence for municipal income per capita and labor productivity during the same period. The econometric analysis for the period 1919-2000 is refined in three ways. Firstly, by assuming spatial correlation among variables of the model; secondly, by disaggregating the model for urban and rural activities; and, thirdly, by enlarging the model to take account of the factors conditioning the patterns of spatial growth convergence in the twentieth century. The final section summarizes the results and proposes research extensions. The database is described in Reis (2014).

The main findings of the chapter are: (1) Municipal concentration of income per capita in Brazil, both between and within regions, is extremely high and has deep historical roots. (2) Spatial convergence of income per capita since 1872 has been very slow when compared to the economies of Europe, the USA, and Japan. (3) Spatial convergence, if any, was particularly slow during the import substitution phase from 1920 to 1980 compared to the primary export-led phases that took place in the other periods. (4) The main factors conditioning the growth of municipal income per capita from 1920 to 2000 are the conditions of accessibility (measured by the index of potential market in 1920) and transport infrastructure (measured by the presence of a railroad station in 1920), as well as the share of foreigners in total population in 1920. (5) The effects of railroad on urban output and foreigners on rural output were persistent throughout the decades. (6) Otherwise, institutional factors measured by variables like concentration of wealth (farm ownership in 1920), illiteracy rates in 1920, electoral participation in 1914, and share of slaves back in 1872 , individually or jointly considered, have no significant effects on the growth of municipalities from 1920 to 2000. Thus, except by the effects of foreigner's contribution, it is fair to say that institutions played no role and therefore the chapter endorses the preeminence of geographic factors as determinants of the growth of Brazilian municipalities during the twentieth century. 


\section{Geography and History}

The main historical driver of the geographic patterns of economic development in Brazil was the prohibitive transport costs to the hinterland imposed by the strong declivity of the coastal mountain range running parallel to the Atlantic shoreline (Ellis 1951; Goulart Filho and Queiroz 2011; Silva 1949; Summerhill 2003). The slope of the Serra do Mar-reaching $1000 \mathrm{~m} 100 \mathrm{~km}$ away from the sea-complemented by the intense summer rainfall and the dense rainforest hindered the development of a transportation infrastructure and therefore the economic settlement of the Brazilian hinterland.

In the Northeast region, the Borborema Range as well as the poor soil and dry climate of the Semiarid areas made agricultural settlements hardly unsustainable beyond the seashore strip occupied by the sugar plantations since early colonial times (Milet 1881; Andrade 1973). The settlement of the mining areas in the CenterSouth region during the eighteenth century was made feasible by the negligible transport costs - high specific value - of precious minerals (Cano 1973). But with historical hindsight, it is fair to say that after the exhaustion of mines, high transport costs became a severe constraint to the economic development of the region during most of the nineteenth century (Martins 2004; Bergad 1999; Libby 1988). Finally, in the Amazon region where navigable rivers sanctioned low transport costs, the wild vegetation, unhealthy climate, and the poor quality of soil precluded agrarian settlement up to the last quarter of the twentieth century. Starting in 1850, however, rubber extraction supported a thriving regional economy up to 1912 when the competition of Asian plantations brought the collapse to rubber prices and export values (Santos 1980; Weinstein 1983). ${ }^{1}$

The railroad investments in the third quarter of the nineteenth century were crucial for the viability of agrarian settlements in the hinterland. Transport cost reductions in the order of $80 \%$ pushed the coffee frontier towards western São Paulo (Matos 1974; Milliet 1982; Summerhill 1997; Pinto 1903) and southeast Minas Gerais (Lima 1981, Oliveira 2005). Concomitantly, the city of São Paulo emerged as the most important hub (the node with minimum transport cost) of the railway network, thus pulling industries to exploit economies of scale and emerging as the sustainable industrial growth pole of the country in the beginning of the twentieth century (Cano 1985). For other regions, however, the reduction in transport costs provided by railways had diverse consequences leading to the specialization in agriculture and to the loss of competitiveness in manufacturing and handcraft production which were previously protected by the high transport costs (Cano 1993; Martins 1983; Reis and Monasterio 2010; Restitutti 2008; Stein 1957; Trew 2014).

\footnotetext{
${ }^{1}$ The Brazilian Pampas located in the temperate zones of the extreme south of the country is a double exception to the extent that soils are flat and thus with low transport costs, and high fertility (Bell 1998). Trade costs, however, were high given the frontier situation and the distance to Brazilian domestic and international markets. As a consequence, cattle raising remained as an extractive activity up to the mid-nineteenth century.
} 
Starting in the 1890s, the concentration of industry in São Paulo was enhanced by the synergies and externalities provided by the agglomeration of technological knowledge and human capital of foreign immigrants (Cano 1993; Reis and Monasterio 2010; Versiani 1993). Conversely, subsidized foreign immigration aggravated the segmentation of the Brazilian labor market reducing their effectiveness in reducing regional disparities in productivity and income. Thus, until the 1930s, internal migration to São Paulo was relatively meager despite huge regional differences in productivity and income per capita (Graham 1972; Graham and Hollanda 1971).

In the second half of the twentieth century, government investment in transport infrastructure concentrated on highways which gradually replaced the railroads. The initial impact of the highway option, however, was to reinforce the hegemonic position of São Paulo, thus preserving regional disparities. Indeed, the dispersed network of highways reduced logistics costs of the distribution of manufactured goods in the domestic market in relation to the long haul transport cost incurred to export primary products. Analogously, it reduced the costs of internal migration, thus stimulating the migration flows to large cities and ensuring "unlimited" supply of labor that dampened pressures for urban wage increases, particularly in Sao Paulo and Rio de Janeiro (Barat 1978; Castro 2003; Galvao 1999; Graham 1972; Graham and Hollanda 1971; Oliveira 1977).

During the 1960s, the federal capital moved to Brasília and the federal government started to implement other regional development policies, combining investments in infrastructure, fiscal, and credit incentives. The priority given to highways in detriment of railways was inadequate for the transportation requirements of the agricultural exports from flatlands of the Cerrado areas in the Center-West and North regions of the country. As a consequence, the growth of agricultural productivity and output in these areas were retarded in the last quarter of the century (Castro 2002; Gasques and Yokomizo 1985; Reis and Blanco 2000; Reis and Margullis 1990; Silveira 1957; Weinhold and Reis 2008; Andersen et al. 2002).

From 1968 to 1995, the expansion of the road infrastructure reduced the costs of moving one unit of cargo to São Paulo (a good proxy for the domestic market) more than $40 \%$. Despite that, high transport costs still remain one of the most critical obstacles to Brazilian competitiveness and development. In the Cerrado areas in the Center-West and North regions, in addition to the reduction of transport costs, the profitability of economic activities was enhanced by the possibilities of agricultural mechanization of the flatlands. Another crucial factor in this way was Embrapa's agricultural research which adapted new cultivars - in particular soybeans, rice, and cotton - to the ecological conditions prevailing in the region (Arantes and Souza 1993; Helfand and Rezende 1998; Homma 2003). Naturally, the causal relationships between transport infrastructure, mechanization, and biogeochemical innovations are hard to disentangle. 


\section{Spatial Patterns of Growth, 1872-2000}

This section uses a series of maps and graphs to illustrate the spatial patterns of Brazilian development. The number of Brazilian municípios increased from 642 in 1872 to 5507 in 2000. Thus, to allow consistent inter-temporal analysis, municípios are combined in 432 Minima Comparable Geographic Areas from 1872 to 2000 (MCA 1872-2000; Reis 2008, 2014; Reis et al. 2005, 2011). ${ }^{2}$ Though the time benchmarks of the analysis are primarily determined by Census years, they are useful to provide a fairly broad characterization of the main phases of Brazilian development during the period (Reis et al. 2002).

Figure 1a, f shows the huge spatial disparities of income per capita and labor productivity in 1872. The Northeast, in particular the semiarid areas of the hinterland, was already the poorest region of the country.

The richest areas were located around the city of Rio de Janeiro, which was then the capital and the largest port of the country, and the cities of Rio Grande and Porto Alegre in the extreme south of the country which were the main ports for the fertile Pampas. The high productivity and income per capita levels in the Amazon region are explained by the rubber boom. Note, in passing, that the economic activity in the highlands was practically restricted to the old mining areas of the Center-South region.

From 1872 to 1920 , growth was mainly driven by the export of primary commodities, in particular rubber in the North region and coffee in the Center-South region which pushed the economic frontier in the southwest direction. Figure $1 \mathrm{~b}, \mathrm{~g}$ shows that, in 1920, São Paulo and Rio Grande do Sul display the highest levels of income per capita and labor productivity, both states combining a very productive agriculture with emerging manufacturing activities. By then, the rubber exports in the Amazon had busted.

From 1920 to 1950, the country completed the first stage of industrialization mainly based upon the import substitution of consumer goods. During this period, the city of São Paulo and her surroundings consolidated their place as the dominant industrial pole of the country. Figure $1 \mathrm{c}$, h shows that the concentration of income per capita in São Paulo was intensified by the mid-twentieth century when the processes of urbanization and industrialization reached their peaks. Coffee expansion explains the spread of high income per capita towards the southwest areas of São Paulo and Paraná.

From 1950 to 1980, coupled with an accelerated urbanization process, high trade protection, and strong state intervention, the import substitution industrialization deepened going into durable consumer goods, basic raw materials, and capital goods industries. Despite record high rates of growth, by the end of this period, the Brazilian economy was autarkic and inefficient with a definite policy bias against primary exports. Figure 1d, i shows that, during this period, economic activity

\footnotetext{
${ }^{2}$ The map excludes the State of Acre because in 1872 she was still part of Bolivian territory; only in 1905 she became part of the Brazilian territory.
} 


\begin{tabular}{|l|c|c|}
\hline Year & $\begin{array}{c}\text { Figures A to E } \\
\text { Income per capita (GDP/Population) }\end{array}$ & $\begin{array}{c}\text { Figures F to J } \\
\text { Labor productivity (GDP/Labor force) }\end{array}$ \\
\hline 1872 & & \\
\hline 1919 & & \\
\hline 1950 & & \\
\hline
\end{tabular}

Fig. 1 Brazil: Geographic distribution (AMC 1872-2000) of income per capita (GDP/population) and of labor productivity (GDP/labor force) in (a, f) 1872, (b, g) 1919, (c, h) 1949, (d, i) 1980, and (e, j) 2000 (units and scale variable). Source: IBGE and author's estimates

definitely turned towards the northwest direction led by the move of the federal capital to Brasilia as well as by other regional policies which fostered the expansion of the agricultural crops like cattle, rice, soybean, and corn.

After 1980, autarky and inefficiency charged their tolls with debt crisis, hyperinflation, and stagnation. In the ensuing decades the unavoidable policies were 


\section{Curva de Lorenz da distribuição do PIB municipal segundo a população municipal, 1872-2000}

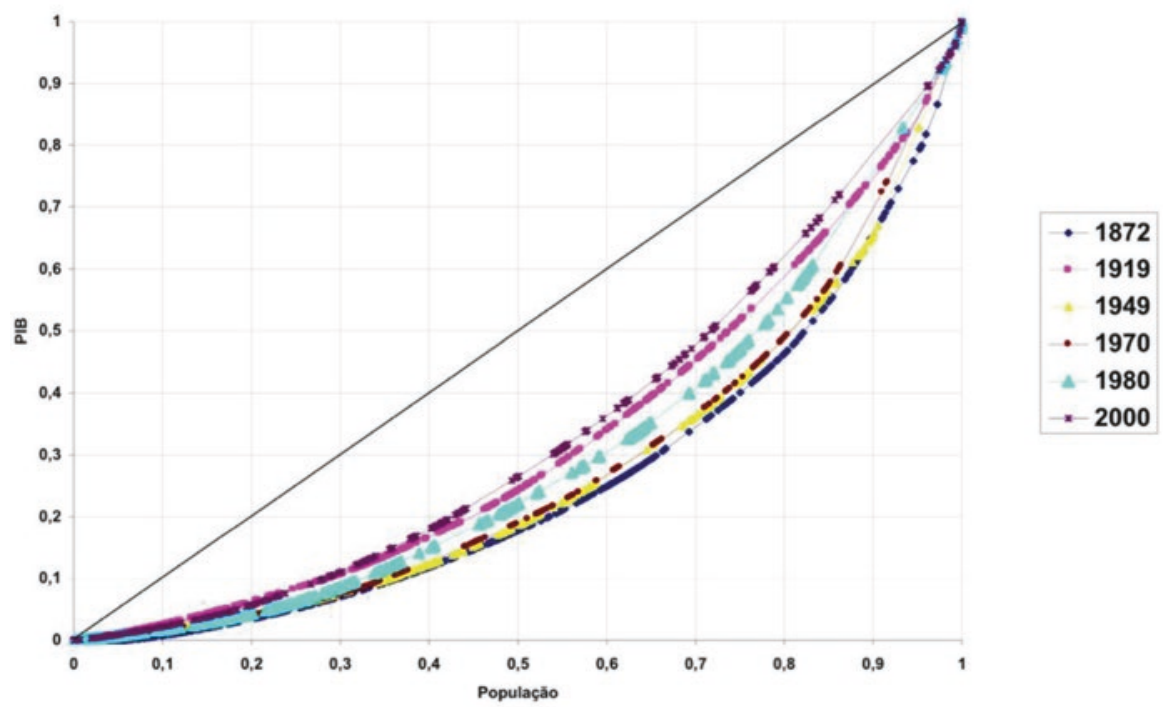

\section{Source: Author's estimates}

Fig. 2 Lorenz curves of the municipal distributions of GDP according to municipal population, 1872-2000. Source: Author's estimates

stabilization, fiscal adjustment, and liberalization which are still lurking. Trade liberalization policies eliminated a large part of the bias against exports of primary commodities which became one of the main sources of growth during this period. On top of that, the country faced the end of the urbanization process and the emergence of population ageing. With the vanishing of import substitution policies, the high levels of income per capita started spreading towards the agricultural frontier in the Center-West and North regions. São Paulo and Rio Grande do Sul kept their leading positions while the Northeast region lagged far behind the rest of the country. By 2000, both in terms of income per capita and labor productivity, the secular divide of the country in the northwest-southeast direction still persisted. ${ }^{3}$

Closing this section, Fig. 2 presents Lorenz curves for the municipal income per capita distribution for the Census years. ${ }^{4}$ The highest spatial concentration took place in $1872($ Gini $=0.45)$ with the respective Lorenz curves practically enveloping

\footnotetext{
${ }^{3}$ It is curious to observe that his division line resembles the southern boundaries of the InterTropical Convergence Zone (ITCZ) observed in the Brazilian territory around January-April, thus suggesting that geographic factors like El Niño might have a persistent effect on the spatial distributions of labor productivity and income per capita.

${ }^{4}$ To be precise, Gini coefficients refer to the 432 comparable areas from 1872 to 2000 and not to municipalities in each Census year. For that reason inequality figures are downward biased. Using comparable areas for 1970-2000, Gini coefficients are 0.5 in 1970, 0.45 in 1980, and 0.41 in 2000, but not strictly comparable with previous Census years.
} 
the other years. Conversely, the lowest spatial concentration took place in 2000 $($ Gini $=0.32)$ with a Lorenz curve that is practically enveloped by all the other years. But the process of spatial dispersion of income per capita was far from monotonic. The curves display a strong dispersion from 1872 to 1919 (Gini decreases from 0.45 to 0.36 ), when the economy was driven by coffee and rubber exports, and more so from 1970 to 2000 (Gini decreases from 0.45 to 0.32 ) when growth was driven by mining and the agricultural frontier in the Cerrado areas of the Center-West region. Conversely, there is strong concentration from 1919 to 1970 (Gini increases from 0.36 to 0.45 ) during the heydays of urbanization and import substitution industrialization. It should be kept in mind, however, that during the import substitution period growth rates of the economy were significantly higher.

\section{Secular Patterns of Convergence of Labor Productivity and Income Per Capita in Brazil, 1872-2000}

This section analyzes the patterns of spatial convergence of municipal income per capita and labor productivity from 1872 to 2000 . For this purpose, it estimates very simple convergence models where the growth rates of income per capita and of labor productivity in a period of time are specified as a function of the respective variable - income per capita or labor productivity - in the initial year of the period in case.

The basic specification of the convergence model is thus

$$
\log \left(y_{i, t} / y_{i, t-n}\right)^{1 / n}=\alpha+\beta \cdot \log \left(y_{i, t-n}\right)
$$

where

$y_{i, t}=\left(Y_{i, t} / \mathrm{Pop}_{i}\right)$ is GDP per capita (or GDP per labor force) in municipality $i$, Census year; $Y_{i, t}$ is GDP per capita in municipality $i$, Census year $t$; and Pop $_{i, t}$ is population (or labor force) in municipality $i$, Census year $t$. $\beta$ is an estimated coefficient that measures the speed of convergence of income per capita (or labor productivity) of municipalities.

To further investigate the processes of convergence estimations were also made assuming spatial autocorrelation in both the dependent (SACD) and residual (SACR) variables of the equations.

The first model (SACD) assumes spatial inertia in the growth of income or of labor productivity. Thus, without specifying the underlying causes, the model assumes that growth is transmitted to contiguous municipalities through contagion. Emulation, migration of labor, capital, and/or technology are possible explanations of the contagious processes.

The second model (SACR) assumes that the residuals of the growth variables are subject to spatial autocorrelation. That is, the determinants of the growth processes 
other than the initial income per capita or labor productivity, though unknown, are supposed to be subject to spatial inertia as in the case of most geographic variables, or else to be subject of spatial contagion through markets, social contacts, shared local culture, or institutions. Note, however, that the speed of convergence is now measured among groups of contiguous municipalities that have some common unspecified determinants of the growth of productivity. In this way, it is a convergence conditionally measured. Spatial clusters of municipalities are converging to different steady-state levels of income per capita or labor productivity.

Estimates of $\beta$, the speed of municipal convergence, of both income per capita (GDP/Population) and labor productivity (GDP/Labor force) for the three models in the 1872-2000 period, as well as for the subperiods 1872-1919, 1919-2000, 19191949, 1949-1980, and 1980-2000, are presented in columns 2-5 of Table 1 (Reis 2014 for more detailed results). Columns 3 and 5 show the coefficients of spatial autocorrelations (SAC) of the dependent variables and the residuals of the respective equation.

Before coming to the regression results it is interesting to observe that, in the period 1872-2000, average municipal growth rates were slightly higher for income per capita ( $1.80 \%$ p.a.) than for labor productivity (1.65\% p.a.), thus indicating that, on average, labor force grew a bit faster than population, that is, on average, the dependency ratio increased $0.015 \%$ during this period. Equivalent figures for 1920 2000 are $3.4 \%$ p.a. and $4.5 \%$ p.a., respectively, thus indicating that, on average, the dependency ratio decreased $1.1 \%$ p.a.

For the whole 1872-2000 period, OLS estimates of $\beta$ for income per capita and labor productivity are -0.006 and -0.005 , both significant at 0.001 probability level. Thus, municipalities with $1 \%$ more in the level of income per capital in 1872 had 0.005 less in their annual average growth rates from 1872 to 2000 . The speed of convergence is quite small and practically the same for both income per capita and labor productivity.

Spatial autocorrelation effects are relatively large for the residual of the equation of income per capita and thus taking account of them makes a difference for the estimate of the speed of convergence of income per capita. Thus, from 1872 to 2000, unexplained geographic as well as other spatially correlated factors (like quality of soil, altitude, climate, distance to sea or to the state capital, culture, institutions) had a significant effect on the growth of municipal income per capita - but not on the productivity of labor.

Looking across subperiods, note first that the speed of convergence, $\beta$, for the 1872-1919 period shows a significant increase for labor productivity but not for income per capita. A suggested explanation is the effects on labor productivity of the changes in the dependency ratio and women participation rates related to the demise of slavery and impact of foreign immigration. The second observation is that spatial autocorrelation of the residuals in the equation of labor productivity is much higher for this period but the convergence of labor productivity is not much affected. 


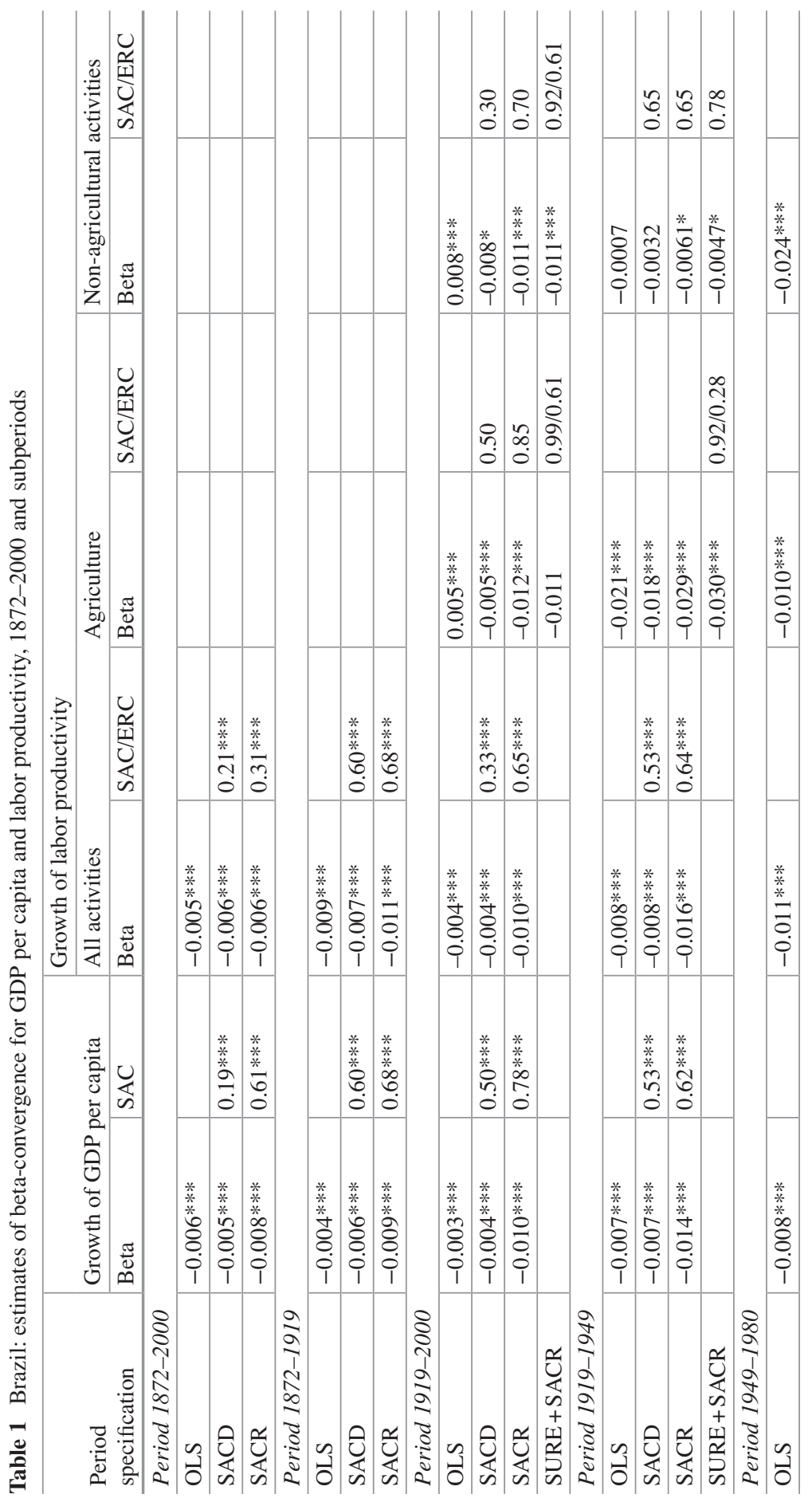




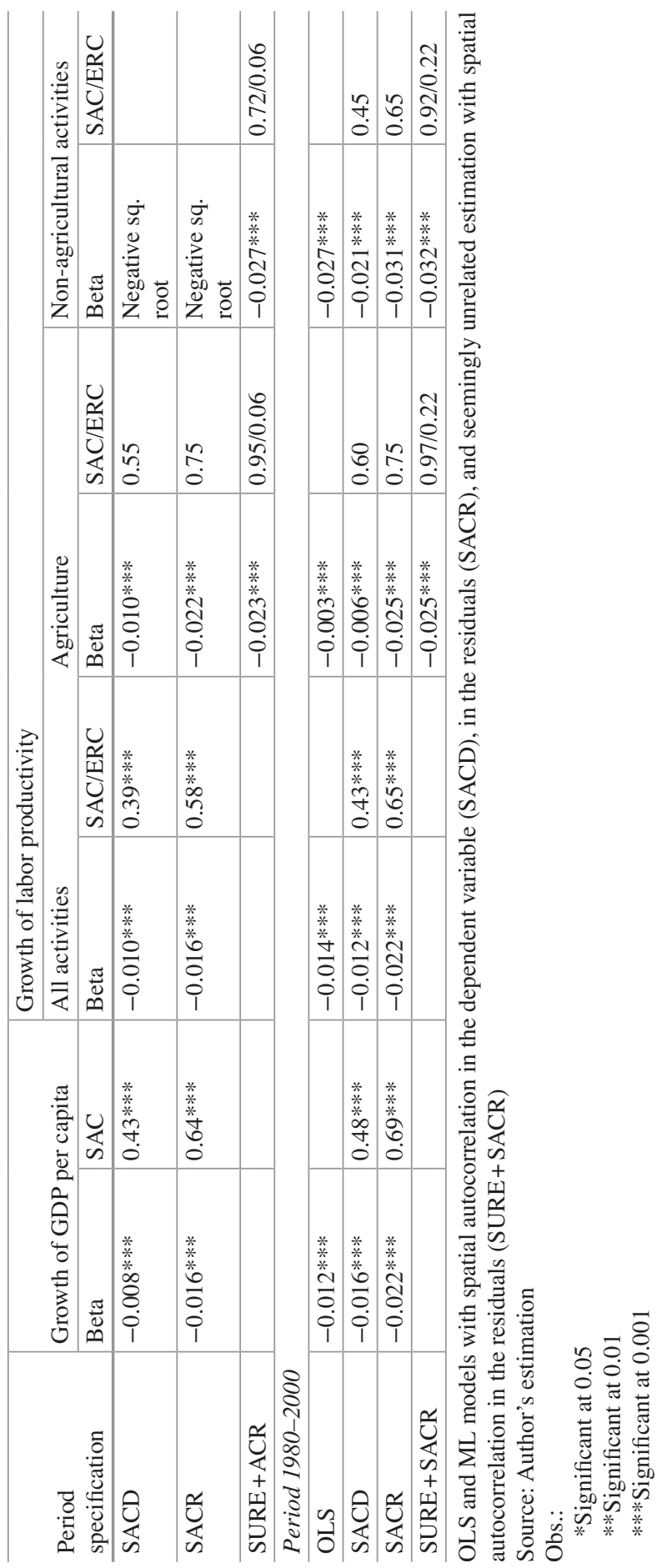


From 1920 to 2000, the speed of convergence of income per capita and labor productivity became even slower, except for the estimation taking account of the spatial autocorrelation of residuals of the respective equations. Thus, geographic as well as other factors correlated in space played an even more important role in the processes of municipal growth during the twentieth century. Looking at specific subperiods, however, the speed convergence is relatively faster, particularly from 1980 to 2000 .

It is difficult to pinpoint the forces shaping this historical pattern of convergence. From 1872 to 1919, the collapse of rubber frontier in the North Region is part of the explanation of the slower rates of convergence estimated. From 1919 to 1980, the import substitution industrialization was associated with urban concentration, economies of scale, and agglomeration, thus implying the slow rates of convergence of income and productivity. After 1970, regional government policies coupled with the natural resources content of the exports of minerals and agricultural commodities were responsible for the faster growth dispersion in both industry and agriculture. It should be kept in mind, however, that average growth rates were much higher in the import substitution phases. Finally, changes in the dependency ratio associated with migration and urbanization trends probably played differential roles across subperiods.

Compared to other countries, the convergence of municipal income per capita in Brazil was quite slow. Indeed, estimates of $\beta$ are close to -0.02 , both in the case of personal income in the US states in the period 1950-1980 and of income per capita of Japanese municipalities in the period 1955-1987 (Barro and Sala-iMartin 1995). Equivalent estimates for income per capita of Italian municipalities are -0.025 for the period $1951-1970$, and -0.003 for the period 1970-2000 (Arbia et al. 2002; Felice 2013)). The magnitude of those estimates is significantly higher than those estimated for Brazil in the periods 1950-1980 or 1980-2000.

For the whole 1872-2000 period estimations are also disaggregated by main regions - North, Northeast, Center-South, South, and Center-West - to get a more detailed picture of geographic patterns of convergence of income per capita and labor productivity. Results not reported here (see Reis 2014) show that in all regions the speed of convergence was a bit faster than in the country as a whole, thus suggesting a secular process of divergence among regions which was counteracted by a slow process of spatial convergence inside each region. The concentration of import substitution industrialization in the Center-South region of the country and the marked regional contrasts in soil aptitude and agricultural development were, undoubtedly, major factors in process of regional divergence. Inside the regions, the speed of convergence was faster in the South and in the North Region, but slow in the Northeast. For all regions, however, $\beta$ estimates were still exceedingly low in international perspective.

In what follows, the analysis of growth convergence of labor productivity in the period 1919-2000 will be detailed in two ways: first, by the disaggregation of the analysis for urban and rural activities, and, second, by assuming spatial correlation among the variables of the model as well as among equations of describing the 
processes of urban and rural growth. This is made possible because for the 19192000 period the economic censuses allow the estimation of separate convergence equations for labor productivity in rural (agriculture) and urban (nonagricultural) activities. $^{5}$

A preliminary finding is that the average growth of labor productivity was higher in agriculture $(2.6 \%$ p.a.) than in urban activities $(2.4 \%$ p.a.). To a large extent the explanation lies in the weight of the service sector and all kinds of low-productivity informal activities in the growth of urban output and employment.

Convergence was faster for labor productivity than for income per capita, both however extremely low when compared with other countries. The faster convergence of labor productivity is difficult to interpret without further analysis of demographic patterns of growth-dependency ratio, in particular-during this period.

Convergence equation for the growth of labor productivity in rural and urban activities in the 1920-2000 period shows that the speed of convergence was faster for urban activities, though both are still very low compared to international standards. This result sounds reasonable given the relatively footloose characteristics of urban activities, while agriculture depends on the availability of adequate soils and climate which are concentrated in specific areas-particularly in the South and Center-West regions - of the country.

It is interesting to observe that both rural and urban activities show higher speed of convergence than aggregate labor productivity in the economy, thus suggesting that there were synergies and cross-correlations between the processes of growth in labor productivity in both sectors. Rural and labor productivity grew faster or slower in the same areas, thus characterizing patterns of growth high-high or low-low in both sectors.

Finally, the last model combines the assumption of correlation of residuals of the growth convergence equations for labor productivity in urban and rural activities with the assumption of spatial autocorrelation in the residuals of each of the equations (SURE+SACR). The results are pretty similar to the ones obtained with the SACR model. Thus, what matters most for the process of convergence of labor productivity in rural and urban activities is the spatial autocorrelation observed for each of these activities and not the correlation between the growth of productivity in rural and urban activities. Thus, residual factors in the growth convergence equations of labor productivity in the rural and urban activities and the growth of labor productivity in rural and urban activities in the Brazilian economy during the twentieth century were quite independent processes with each of them subject to spatial inertia processes.

\footnotetext{
${ }^{5}$ The sectorial disaggregation is not made for income per capita simply because the Census of 1920 did not collect data on rural and urban population despite collecting data on labor force according to major economic activities.
} 


\section{Factors Conditioning Convergence Patterns, 1920-2000}

To analyze the determinants of the growth patterns of the Brazilian economy in the period 1920-2000, the specifications of the growth convergence equations are enlarged to incorporate the determinants of steady-state growth rates of Brazilian municipalities. This is made by the specification of a conditional model introducing variables like infrastructure, geographical attributes, institutions, and human capital, among others, as exogenous determinants of the growth of municipalities from 1920 to $2000 .^{6}$

In the case of the growth of GDP per capita, the model to be estimated becomes

$$
\log \left(y_{i, t} / y_{i, t-n}\right)^{1 / n}=\alpha+\beta \cdot \log \left(y_{i, t-n}\right)+\gamma \cdot X_{i, t-n}
$$

where

$y_{i, t}=Y_{i, t} / \mathrm{Pop}_{i}$ ( or $Y_{i, t} /$ Labor $_{i}$ ) is the aggregate, urban, or rural labor productivity (GDP/labor force) or GDP per capita of município $i$ in year $t$.

$Y_{i, t}$ is the aggregate, urban, or rural GDP of município $i$ in year $t$; $\operatorname{Pop}_{i, t}$ is the total, urban, or rural population of município $i$ in year $t$.

Labor $_{i, t}$ is the aggregate urban or rural labor force of the município $i$ in year $t$.

$X_{i, t-n}=$ matrix of explanatory variables including all the exogenous variables that explain the steady-state rate of growth of Brazilian municipalities from 1920 to 2000.

The explanatory factors are listed in the first column of Table 2. They include major characteristics of the municipalities in terms of geography (area, latitude, longitude, altitude, temperature, precipitation, soil types, etc.), demography (population, foreign population, labor force), economy (GDP by sectors, landownership concentration, electricity generation, area of farms, share of coffee in cropped area), accessibility and transport (existence and age of railway station, distance to sea, and distance to capital, potential market index), human capital and education (literacy, enrollment, and number of primary schools), and a few institutional dimensions like the number of slaves in 1872 and the number of voters in 1910. Most of the variables refer to 1920. The exceptions are slavery, schools, and voters which were not available for 1920, and, obviously, geographic conditions. For a description of the definition and measurement of exogenous variables see Reis (2014) and Reis et al. (2007).

Estimation results presented in Table 2 show that initial socioeconomic conditions in 1920 explain more than $50 \%$ of the variance of the growth rates of Brazilian municipalities in the period 1920-2000. Note that the OLS estimations of simple growth convergence in equations of Table 2 explained around $15 \%$.

The speed of convergence is approximately equal to 1 for both income per capita and labor productivity. For urban and agriculture activities the estimates for GDP per worker are 1.2, approximately. These values are relatively small given that they

\footnotetext{
${ }^{6}$ It was not possible to extend the analysis to 1872 because all the conditional variables available were used to estimate income per capita for this year, thus making them unavoidably correlated to endogenous variables.
} 
Table 2 Brazil: OLS estimation of conditional growth convergence of GDP per capita and labor productivity in urban and rural activities, 1919-2000

\begin{tabular}{|c|c|c|c|c|c|}
\hline \# & & $\begin{array}{l}\text { Growth of } \\
\text { GDP per } \\
\text { capita } \\
1919-2000\end{array}$ & $\begin{array}{l}\text { Growth of } \\
\text { aggreg. labor } \\
\text { productivity } \\
\text { 1919-2000 }\end{array}$ & $\begin{array}{l}\text { Growth of } \\
\text { rural labor } \\
\text { productivity } \\
1919-2000\end{array}$ & $\begin{array}{l}\text { Growth of } \\
\text { urban labor } \\
\text { productivity } \\
1919-2000\end{array}$ \\
\hline 1 & N. obs. & 397 & 397 & 395 & 397 \\
\hline 2 & $F$-value & 7.193 & 6.898 & 8.600 & 6.632 \\
\hline 3 & $R$-square & 0.552 & 0.541 & 0.597 & 0.532 \\
\hline 4 & Adj. $R$-square & 0.475 & 0.463 & 0.527 & 0.451 \\
\hline 5 & Dependent mean & 0.034 & 0.030 & 0.026 & 0.024 \\
\hline 6 & Root MSE & 0.006 & 0.005 & 0.008 & 0.006 \\
\hline 7 & Coeff. var. & 16.567 & 18.419 & 32.072 & 22.852 \\
\hline 8 & Variables & & & & \\
\hline 9 & Intercept & $-0.188 * *$ & $-0.155^{*}$ & -0.065 & -0.098 \\
\hline 10 & $\begin{array}{l}\text { Log (GDP per capita } \\
\text { 1919) }\end{array}$ & $-0.010 * *$ & & & \\
\hline 11 & $\begin{array}{l}\text { Log (labor } \\
\text { productivity 1919) }\end{array}$ & & $-0.010 * *$ & & \\
\hline 12 & $\begin{array}{l}\text { Log (labor } \\
\text { productivity rural } \\
1919 \text { ) }\end{array}$ & & & $-0.012 * *$ & \\
\hline 13 & $\begin{array}{l}\text { Log (labor } \\
\text { productivity urban } \\
\text { 1919) }\end{array}$ & & & & $-0.012 * *$ \\
\hline 14 & $\begin{array}{l}\text { Log (population in } \\
1920 \text { ) }\end{array}$ & -0.004 & -0.005 & -0.005 & -0.003 \\
\hline 15 & $\log$ (labor force 1920) & 0.000 & 0.002 & $-0.014^{*}$ & 0.003 \\
\hline 16 & $\begin{array}{l}\text { Log (labor force in } \\
\text { agriculture 1920) }\end{array}$ & 0.002 & 0.002 & $0.012 * *$ & 0.000 \\
\hline 17 & $\begin{array}{l}\text { Log (labor force in } \\
\text { manufacture1920) }\end{array}$ & 0.000 & 0.000 & -0.001 & 0.000 \\
\hline 18 & $\begin{array}{l}\log (\text { foreigners in } \\
1920)\end{array}$ & $0.001 * *$ & $0.001 *$ & $0.002 * *$ & 0.001 \\
\hline 19 & Log (literates in 1920) & 0.001 & 0.000 & 0.004 & -0.002 \\
\hline 20 & $\begin{array}{l}\text { Students public } \\
\text { primary school 1920/ } \\
\text { population } 1920\end{array}$ & -0.128 & -0.108 & 0.018 & -0.077 \\
\hline 21 & $\begin{array}{l}\text { Students private } \\
\text { primary school 1920/ } \\
\text { population } 1920\end{array}$ & 0.084 & 0.082 & 0.158 & 0.106 \\
\hline 22 & $\begin{array}{l}\text { Number of state } \\
\text { primary schools in } \\
1920 / \text { population in } \\
1920\end{array}$ & 2.300 & 1.978 & 0.487 & 0.755 \\
\hline 23 & $\begin{array}{l}\text { Number of private } \\
\text { primary schools in } \\
1920 \text { /population in } \\
1920\end{array}$ & 3.313 & 2.582 & -0.684 & -0.899 \\
\hline
\end{tabular}


Table 2 (continued)

\begin{tabular}{|c|c|c|c|c|c|}
\hline \# & & $\begin{array}{l}\text { Growth of } \\
\text { GDP per } \\
\text { capita } \\
1919-2000\end{array}$ & $\begin{array}{l}\text { Growth of } \\
\text { aggreg. labor } \\
\text { productivity } \\
1919-2000\end{array}$ & $\begin{array}{l}\text { Growth of } \\
\text { rural labor } \\
\text { productivity } \\
1919-2000\end{array}$ & $\begin{array}{l}\text { Growth of } \\
\text { urban labor } \\
\text { productivity } \\
1919-2000\end{array}$ \\
\hline 24 & $\begin{array}{l}\text { Dummy for railway } \\
\text { station in } 1920\end{array}$ & $0.148 *$ & $0.141^{*}$ & -0.066 & $0.153 * *$ \\
\hline 25 & $\begin{array}{l}\text { Inaugural year of } \\
\text { railway in the } \\
\text { municipality }\end{array}$ & $0.000^{*}$ & $0.000^{*}$ & 0.000 & $0.000 * *$ \\
\hline 26 & $\begin{array}{l}\text { Dummy for electricity } \\
\text { generation station in } \\
1920\end{array}$ & 0.277 & 0.298 & 0.254 & 0.340 \\
\hline 27 & $\begin{array}{l}\text { Inaugural year of } \\
\text { electricity in the } \\
\text { municipality }\end{array}$ & 0.000 & 0.000 & 0.000 & 0.000 \\
\hline 28 & $\begin{array}{l}\text { Number of electrical } \\
\text { motors in municipality } \\
1920\end{array}$ & -0.001 & -0.001 & 0.000 & -0.001 \\
\hline 29 & $\begin{array}{l}\text { Power of electrical } \\
\text { motors in municipality } \\
1920 \text { (Kwh) }\end{array}$ & $0.000^{*}$ & $0.000^{*}$ & 0.000 & $0.000^{*}$ \\
\hline 30 & $\begin{array}{l}\text { Number of enterprises } \\
\text { generating } \\
\text { hydroelectricity } 1920\end{array}$ & $0.001 *$ & $0.001^{*}$ & 0.000 & $0.001^{*}$ \\
\hline 31 & $\begin{array}{l}\text { Number of registered } \\
\text { voters in 1914/ } \\
\text { Population in } 1920\end{array}$ & -0.011 & -0.005 & $-0.070 *$ & 0.002 \\
\hline 32 & $\begin{array}{l}\text { Share of slaves in total } \\
\text { population } 1872\end{array}$ & 0.007 & 0.006 & 0.000 & 0.006 \\
\hline 33 & $\begin{array}{l}\text { Log (area of } \\
\text { agricultural } \\
\text { establishments in } \\
\text { 1920) }\end{array}$ & 0.001 & 0.001 & $0.002 * *$ & 0.001 \\
\hline 34 & $\begin{array}{l}\text { Crop area of coffee } \\
1920 \text { /area of farms } \\
1920\end{array}$ & -0.005 & -0.006 & 0.008 & -0.001 \\
\hline 35 & $\begin{array}{l}\text { Theil index of } \\
\text { landownership } \\
\text { inequality in } 1920\end{array}$ & 0.000 & 0.000 & 0.000 & 0.000 \\
\hline 36 & $\begin{array}{l}\text { Log (GDP potential } \\
\text { market in 1919) }\end{array}$ & $0.007 * *$ & $0.007 * *$ & -0.002 & $0.006^{* *}$ \\
\hline 37 & $\begin{array}{l}\text { Log (geographic area } \\
\text { of AMC) }\end{array}$ & 0.000 & 0.000 & -0.001 & 0.000 \\
\hline 38 & $\begin{array}{l}\text { Latitude of seat of } \\
\text { municipality }\end{array}$ & -0.0003 & -0.0002 & $-0.0015^{* *}$ & 0.0000 \\
\hline 39 & $\begin{array}{l}\text { Longitude of } \\
\text { municipality seat }\end{array}$ & 0.0001 & 0.0001 & 0.0002 & 0.0000 \\
\hline
\end{tabular}


Table 2 (continued)

\begin{tabular}{|c|c|c|c|c|c|}
\hline \# & & $\begin{array}{l}\text { Growth of } \\
\text { GDP per } \\
\text { capita } \\
1919-2000\end{array}$ & $\begin{array}{l}\text { Growth of } \\
\text { aggreg. labor } \\
\text { productivity } \\
\text { 1919-2000 }\end{array}$ & $\begin{array}{l}\text { Growth of } \\
\text { rural labor } \\
\text { productivity } \\
1919-2000\end{array}$ & $\begin{array}{l}\text { Growth of } \\
\text { urban labor } \\
\text { productivity } \\
\text { 1919-2000 }\end{array}$ \\
\hline 40 & $\begin{array}{l}\text { Dummy for state } \\
\text { capital }\end{array}$ & $0.0050 * *$ & $0.0038^{*}$ & 0.0004 & 0.0032 \\
\hline 41 & $\begin{array}{l}\text { Geodesic distance to } \\
\text { the state capital (in } \\
\mathrm{km} \text { ) }\end{array}$ & 0.0000 & 0.0000 & $0.0000 * *$ & 0.0000 \\
\hline 42 & $\begin{array}{l}\text { Geodesic distance to } \\
\text { the sea (in } \mathrm{km} \text { ) }\end{array}$ & 0.0000* & $0.0000 *$ & 0.0000 & 0.0000 \\
\hline 43 & $\begin{array}{l}\text { Share of area w/ } \\
\text { altitude } 0 \text { a } 99 \mathrm{~m}\end{array}$ & $0.007 * *$ & $0.007 * *$ & 0.006 & $0.009 * *$ \\
\hline 44 & $\begin{array}{l}\text { Share of area w/ } \\
\text { altitude } 200 \text { a } 499 \mathrm{~m}\end{array}$ & -0.002 & -0.003 & 0.002 & -0.001 \\
\hline 45 & $\begin{array}{l}\text { Share of area w/ } \\
\text { altitude } 500 \text { a } 799 \mathrm{~m}\end{array}$ & 0.001 & 0.000 & $0.008^{*}$ & 0.002 \\
\hline 46 & $\begin{array}{l}\text { Share of area w/ } \\
\text { altitude } 800 \text { a } 1199 \mathrm{~m}\end{array}$ & 0.002 & 0.000 & 0.000 & 0.001 \\
\hline 47 & $\begin{array}{l}\text { Share of area w/ } \\
\text { altitude } 1200 \text { a } \\
1799 \mathrm{~m}\end{array}$ & -0.007 & -0.005 & 0.006 & -0.002 \\
\hline 48 & $\begin{array}{l}\text { Share of area w/ } \\
\text { altitude } 1800 \mathrm{a} \\
3000 \mathrm{~m}\end{array}$ & -0.131 & -0.127 & 0.105 & -0.125 \\
\hline 49 & $\begin{array}{l}\text { Share of area } \\
7.5-15 \% \text { declivity- } \\
\text { moderate erosion }\end{array}$ & -0.006 & -0.005 & -0.006 & -0.003 \\
\hline 50 & $\begin{array}{l}\text { Share of area } 30-45 \% \\
\text { declivity-strong } \\
\text { erosion }\end{array}$ & -0.005 & -0.004 & -0.006 & -0.004 \\
\hline 51 & $\begin{array}{l}\text { Share of municipal } \\
\text { soil in class } 1\end{array}$ & $0.158^{*}$ & $0.144 *$ & 0.062 & 0.093 \\
\hline 52 & $\begin{array}{l}\text { Share of municipal } \\
\text { soil in class } 2\end{array}$ & $0.160 *$ & $0.145^{*}$ & 0.058 & 0.095 \\
\hline 53 & $\begin{array}{l}\text { Share of municipal } \\
\text { soil in class } 3\end{array}$ & $0.144 *$ & $0.128 *$ & 0.054 & 0.080 \\
\hline 54 & $\begin{array}{l}\text { Share of municipal } \\
\text { soil in class } 4\end{array}$ & $0.150^{*}$ & $0.136^{*}$ & 0.057 & 0.087 \\
\hline 55 & $\begin{array}{l}\text { Share of municipal } \\
\text { soil in class } 5\end{array}$ & $0.149 *$ & $0.135^{*}$ & 0.048 & 0.091 \\
\hline 56 & $\begin{array}{l}\text { Share of municipal } \\
\text { soil in class } 6\end{array}$ & $0.156^{*}$ & $0.141^{*}$ & 0.061 & 0.092 \\
\hline 57 & $\begin{array}{l}\text { Share of municipal } \\
\text { soil in class } 7\end{array}$ & $0.160 *$ & $0.145^{*}$ & 0.059 & 0.096 \\
\hline 58 & $\begin{array}{l}\text { Share of municipal } \\
\text { soil in class } 8\end{array}$ & $0.158^{*}$ & $0.143^{*}$ & 0.058 & 0.094 \\
\hline
\end{tabular}


Table 2 (continued)

\begin{tabular}{l|l|l|l|l|l}
\hline$\#$ & & $\begin{array}{l}\text { Growth of } \\
\text { GDP per } \\
\text { capita } \\
1919-2000\end{array}$ & $\begin{array}{l}\text { Growth of } \\
\text { aggreg. labor } \\
\text { productivity } \\
1919-2000\end{array}$ & $\begin{array}{l}\text { Growth of } \\
\text { rural labor } \\
\text { productivity } \\
1919-2000\end{array}$ & $\begin{array}{l}\text { Growth of } \\
\text { urban labor } \\
\text { productivity } \\
1919-2000\end{array}$ \\
\hline 59 & $\begin{array}{l}\text { Share of municipal } \\
\text { soil in class 9 }\end{array}$ & $0.161^{*}$ & $0.148^{*}$ & 0.083 & 0.084 \\
\hline 60 & $\begin{array}{l}\text { Share of municipal } \\
\text { soil in class 10 }\end{array}$ & $0.156^{*}$ & $0.141^{*}$ & 0.058 & 0.092 \\
\hline 61 & $\begin{array}{l}\text { Share of municipal } \\
\text { soil in class 11 }\end{array}$ & $0.146^{*}$ & $0.131^{*}$ & 0.055 & 0.083 \\
\hline 62 & $\begin{array}{l}\text { Share of municipal } \\
\text { soil in class 12 }\end{array}$ & -0.049 & -0.068 & 0.309 & -0.159 \\
\hline 63 & $\begin{array}{l}\text { Average precipitation } \\
\text { Dec-Feb 1961-1990 }\end{array}$ & $-0.00005^{*}$ & -0.00003 & 0.00003 & -0.00004 \\
\hline 64 & $\begin{array}{l}\text { Average precipitation } \\
\text { Jun-Aug 1961-1990 }\end{array}$ & $-0.00004^{*}$ & -0.00002 & $0.00009 * *$ & -0.00002 \\
\hline 65 & $\begin{array}{l}\text { Average precipitation } \\
\text { Mar-May 1961-1990 }\end{array}$ & 0.00004 & 0.00003 & 0.00000 & 0.00000 \\
\hline 66 & $\begin{array}{l}\text { Average precipitation } \\
\text { Sep-Nov 1961-1990 }\end{array}$ & 0.00002 & 0.00000 & -0.00007 & 0.00003 \\
\hline 67 & $\begin{array}{l}\text { Average temperature } \\
\text { Dec-Feb 1961-1990 }\end{array}$ & -0.00210 & -0.00138 & $-0.00613 * *$ & 0.00039 \\
\hline 68 & $\begin{array}{l}\text { Average temperature } \\
\text { Jun-Aug 1961-1990 }\end{array}$ & -0.00129 & -0.00040 & $-0.00507^{* *}$ & 0.00092 \\
\hline 69 & $\begin{array}{l}\text { Average temperature } \\
\text { Mar-May 1961-1990 }\end{array}$ & 0.00189 & 0.00115 & $0.00549 *$ & -0.00136 \\
\hline 70 & $\begin{array}{l}\text { Average temperature } \\
\text { Sep-Nov 1961-1990 }\end{array}$ & 0.00100 & 0.00009 & $0.00743 * *$ & -0.00060 \\
\hline S0urc: Aut & & & & \\
\hline 6
\end{tabular}

Source: Author's estimates (pib14si.xls)

Obs.:

*Significant at $5 \%$ level

**Significant at $1 \%$ level

refer to estimates of the speed of conditional growth convergence of municipalities which had similar conditions in 1920. Thus, even among municipalities with similar initial conditions the speed of convergence is slow compared to other countries.

In Table 2 the variables with estimated coefficients significant at 5\% level are considered relevant as growth factors and as such marked with one asterisk. Two asterisks denote the threshold of $1 \%$ significance level. Whenever meaningful, variables were specified as logarithm except when there is a high incidence of null observations in which case they were specified in per capita terms.

Estimation results show that population in 1920 is not significant in all the equations (marginally in the case of the growth labor productivity) but is kept as a normalizing variable for all the other variables.

The most important variable is the dummy for the existence of a railway station in 1920. Ceteris paribus, that would imply an increase of $14 \%$ p.a. in average growth rates from 1920 to 2000 . This a huge impact but is restricted to urban activities; 
growth rates of agricultural productivity were not significantly affected by the existence of a railroad in 1920. The problem with the estimation of this coefficient is that railroad stations could be capturing the effects of omitted variables related to transportation costs, accessibility, and other previous locational advantages. Places which had previous advantages in terms of access and natural resources availability were likely to grow faster in the long run and to that extent railroad stations would be endogenously located and its coefficient biased upward. A possible solution would be to use as instrumental variables describing transport accessibility previous to railways like, for example, distance to main seaports by mule troops in prerailways times. The difficulty, however, is the ubiquity of mule roads which imposes the need of some qualification. A better alternative, perhaps, would be to use transport costs to main markets instead of railroad station. Our future research will be directed in both ways.

The age of the railway station is also significant though it has very small positive effect on the average growth rate. Early comers in the railway access have had a small lasting growth advantage.

To be a state capital was also an important factor for the secular growth rate of both income per capita and labor productivity. The increases in average growth rates in the period 1920-2000 were $0.5 \%$ for GDP per capita and $0.4 \%$ for GDP per worker. The suggested explanation is the better accessibility to all kinds of infrastructure and government services. Surprisingly, perhaps, when we disaggregate the results, the effect is only marginally significant in the growth for urban activities, and, as expected, not significant for the growth of agricultural productivity.

The distance to a state capital, however, had a positive effect on the growth rate of labor productivity in agriculture but none on the other growth variables. It looks like as the consequence of home market effects or some form of access to technology, since state capital is both more rich and populated as well as sources of knowledge and human capital.

Other infrastructure variables with significant effects have to do with electricity generation. Both the number of companies of electricity generation installed in a municipality in 1920 and their capacity of generation (in Kw) in that same year had a significant positive effect on the secular growth rate of GDP per capita and per worker. Each additional company brings $0.1 \%$ of increase in the annual average secular growth of the municipality. The effect is wholly due to industry. Growth rates of GDP per worker in agriculture are not affected by electricity infrastructure, as we should expect, given the fact the electrification of rural areas was practically absent in 1920.

Apart from infrastructure, the other important factor is the potential market of the municipality in 1920 measured by the average GDP of Brazilian municipalities weighted by the inverse of their geographic distances to the municipality in case. Each percent implied $0.001 \%$ more of average growth rates in 1920-2000. Thus, municipalities that were close to rich municipalities in 1920 grew more in the 19202000 period. Thus, market agglomeration effects were important and, as a consequence, demand factors and historical accidents probably played important roles in the spatial pattern of growth. 
Foreign-born population was also an important factor of productivity and income per capita growth. Interestingly, however, the effect was mainly felt in the growth of agricultural productivity. For the growth of urban productivity it was not significant. Suggested explanations are capital, technology, human capital, as well as cultural and institutional innovations introduced by the immigrants in the agricultural sector. ${ }^{7}$ It could as well be that migrants anticipated the agricultural growth prospects of the areas for where they migrated. In that case, the coefficient would be biased upward. Note, however, that coffee as percent of agricultural establishments is not a significant explanatory variable. And apart from that fact, it is difficult to envisage their successful prospection methods, in particular because they were likely to be ignorant about the agronomic conditions and growth possibilities of the different areas.

Agricultural activities tend to show some inertial or cumulative features in that the growth of agricultural productivity was higher in the municipalities with larger labor force in agriculture and area of a larger share of agricultural establishments in 1920. Note, however, that the size of total labor force tends to decrease the growth of agricultural productivity.

Geographic variables have some expected effects and other quite surprising. Thus, the effects of temperature and precipitation on the growth of GDP per capita are not significant. Moreover, the significance of soils in GDP per capita growth is probably capturing the the effects of state dummy that should be introduced as shown by the joint significance tests reported below.

Finally, the model tests the importance of some institutional conditions on the development of municipalities (Engerman and Sokolloff 1997, 2012; Nunn 2007). The proxies of institutional conditions included were the share of slaves in total population in 1872; Theil index for landownership concentration in 1920; a group of variables related to education including the literacy rate of population in 1920, and four other variables describing the availability of schools as well as the attendance of schools in 1907; and, finally, political participation in 1914 as measured by the share of registered voters in total population.

The results show that, surprisingly, solely or jointly considered, none of the institutional proxies selected were statistically significant (at the 5\% level) factors for the growth of Brazilian municipalities in the twentieth century. The only significant proxy of institutional factors is, therefore, the share of foreign-born population in 1920.

To test the institutional hypothesis, variables were jointly tested in three groups of variables composed as follows:

(A) Slavery in $1872+$ Registered voters in $1910+$ landownership concentration in 1920

\footnotetext{
${ }^{7}$ For a thoughtful discussion of the interactions of culture and institutions in the development process, see (Alesina and Giulano 2013). International comparative analysis and evidence on institutional factors can be found in (Lagerloef 2004, 2005) and (Engerman and Sokoloff 2012).
} 
(B) Education condition described by literacy rate in $1920+$ students enrolled in public and private schools in $1910+$ the number of public and private primary schools in 1910

(C) The share of foreign-born population in 1920

As shown in Table 3, F-tests for the joint significance of $\mathrm{A}, \mathrm{B}, \mathrm{A}+\mathrm{B}$, and $\mathrm{A}+\mathrm{B}+\mathrm{C}$ were conducted with the result that, at $5 \%$ confidence level, $\mathrm{A}, \mathrm{B}$, and $\mathrm{A}+\mathrm{B}$ are not significant in all cases. Only $\mathrm{A}+\mathrm{B}+\mathrm{C}$ is significant which is not surprising given that the share of foreign-born population was already significant when singly considered. But in the case of the growth of labor productivity in urban activities even $\mathrm{A}+\mathrm{B}+\mathrm{C}$ is not significant. Thus, climate conditions were binding factors for Brazilian agricultural growth but soil conditions and altitude were circumvented.

Finally, Table 3 also presents test of joint significance for the main geographic factors. Results show that, jointly considered, temperature and precipitation were significant explanatory factors for the growth of rural labor productivity. Surprisingly, however, altitude and geomorphology of soils were significant explanatory factors for the growth of income per capita and of labor productivity in the economy, as well as of the growth of labor productivity in urban areas, but not for the growth of rural labor productivity.

It should be pointed that the prevalence of slavery in 1872 gives a biased picture of the secular and persistent effects of the institution because concentration of the slave population in the booming coffee areas took place in a few decades during the mid-nineteenth century. Indeed, contradicting Nunn (2007), there is a strong positive correlation between the slave share of population in 1872 and the growth of income per capita from 1920 to 2000 . Thus, to some extent the share of slaves in 1872 is also endogenous to the development prospects of this region. To circumvent

Table $3 F$-tests of joint significance for the conditional growth equations of GDP per capita and labor productivity, 1919-2000

\begin{tabular}{|c|c|c|c|c|c|c|c|c|}
\hline \multirow[b]{3}{*}{ Groups of variables } & \multirow{2}{*}{\multicolumn{2}{|c|}{$\begin{array}{l}\text { Growth of GDP } \\
\text { per capita }\end{array}$}} & \multicolumn{6}{|c|}{ Growth of labor productivity } \\
\hline & & & \multicolumn{2}{|c|}{ Aggregate } & \multicolumn{2}{|l|}{ Rural } & \multicolumn{2}{|l|}{ Urban } \\
\hline & $F$-value & $\operatorname{Pr}>F$ & $F$-value & $\operatorname{Pr}>F$ & $F$-value & $\operatorname{Pr}>F$ & $F$-value & $\operatorname{Pr}>F$ \\
\hline $\begin{array}{l}\text { (A) Slave + politic + farm } \\
\text { Theil }\end{array}$ & 1.02 & 0.38 & 0.34 & 0.42 & 1.37 & 0.25 & 0.87 & 0.46 \\
\hline (B) Education & 1.78 & 0.11 & 1.37 & 0.24 & 1.24 & 0.29 & 1.27 & 0.28 \\
\hline (C) $\mathrm{A}+\mathrm{B}$ & 1.51 & 0.15 & 1.23 & 0.28 & 0.96 & 0.47 & 1.13 & 0.34 \\
\hline (D) $A+B+$ foreign & 2.67 & 0,01 & 2.08 & 0.03 & 3.21 & 0.00 & 1.34 & 0.22 \\
\hline (E) Temperature & 0.56 & 0.69 & 0.44 & 0.78 & 6.84 & 0.00 & 0.71 & 0.59 \\
\hline (F) Precipitation & 1.77 & 0.14 & 1.07 & 0.37 & 7.33 & 0.00 & 1.35 & 0.25 \\
\hline (G) Declivity & 1,15 & 0.32 & 1.09 & 0.34 & 0.53 & 0.59 & 0.43 & 0.65 \\
\hline (H) Altitude classes & 3.93 & 0.00 & 4.38 & 0.00 & 1.60 & 0.15 & 4.61 & 0.00 \\
\hline (I) Soil geo-morphol. & 2.30 & 0.01 & 2.31 & 0.01 & 0.67 & 0.78 & 1.73 & 0.06 \\
\hline
\end{tabular}

Source: Author's estimates 
this problem we use instead the data on free black population in 1872 . The rationale is that a large share of free blacks (pardos e pretos livres in 1872) is a better proxy for the historical prevalence of slavery in the municipality and thus to capture the long-run effects of slavery. Though the correlation with secular growth is negative in this case, the coefficients of this variable in the specified model were not significant.

A final interesting question to be posed is how persistent were the effects of railroads stations and foreign-born population in 1920 on the growth of Brazilian municipalities. To analyze this question we estimate the same conditional growth convergence model for each of the subperiods 1919-1950, 1950-1980, and 19802000 , that is, using the same specification except by the year of the lagged dependent variable. Figure 3a, b summarizes the values (and standard deviation) of the coefficients estimated for B-convergence, the station railroad dummy, and the foreign-born population in 1920 for each activity and subperiod. The capped vertical lines show the two standard deviation confidence interval of the estimates of $\beta$, and the figures in parenthesis in the horizontal axis refer to the number of observation for each estimation period. ${ }^{8}$

Figure 3a shows that the effects of 1920 railroad station dummies on growth of municipalities were significant and persistent in the case of labor productivity in industrial and, to a lesser extent, in urban activities. They were practically nonsignificant for income per capita and total productivity and productivity in urban activities. Figure $3 \mathrm{~b}$ shows that the share of foreign-born population had significant pervasive effects from 1919 to 1949 but the lasting effects were restricted to the rural activities.

\section{Conclusions and Extensions}

The basic hypothesis of this chapter is the overwhelming role played by the geographic factors, especially transport costs, in the historical generation and reproduction of spatial inequalities in Brazil. Empirical evidence is presented by the analysis of the spatial patterns of growth of labor productivity and income per capita of the Brazilian municipalities from 1872 to 2000 .

The main result of the analysis is that spatial inequalities in the density of economic activity, income per capita, and labor productivity remained practically unchanged with negligible reductions from 1872 to 2000 . The maps show clearly the secular persistent northwest-southeast divide of income per capita and productivity of the country.

Econometric estimations of models of growth convergence provide a more rigorous test of the hypotheses. Estimation reported shows that the speed of convergence of both income per capita and labor productivity was very slow compared to other countries. Disaggregation of the analysis by subperiods, regions, and sectors shows

\footnotetext{
${ }^{8}$ Regression result not reproduced in the chapter is available upon request.
} 


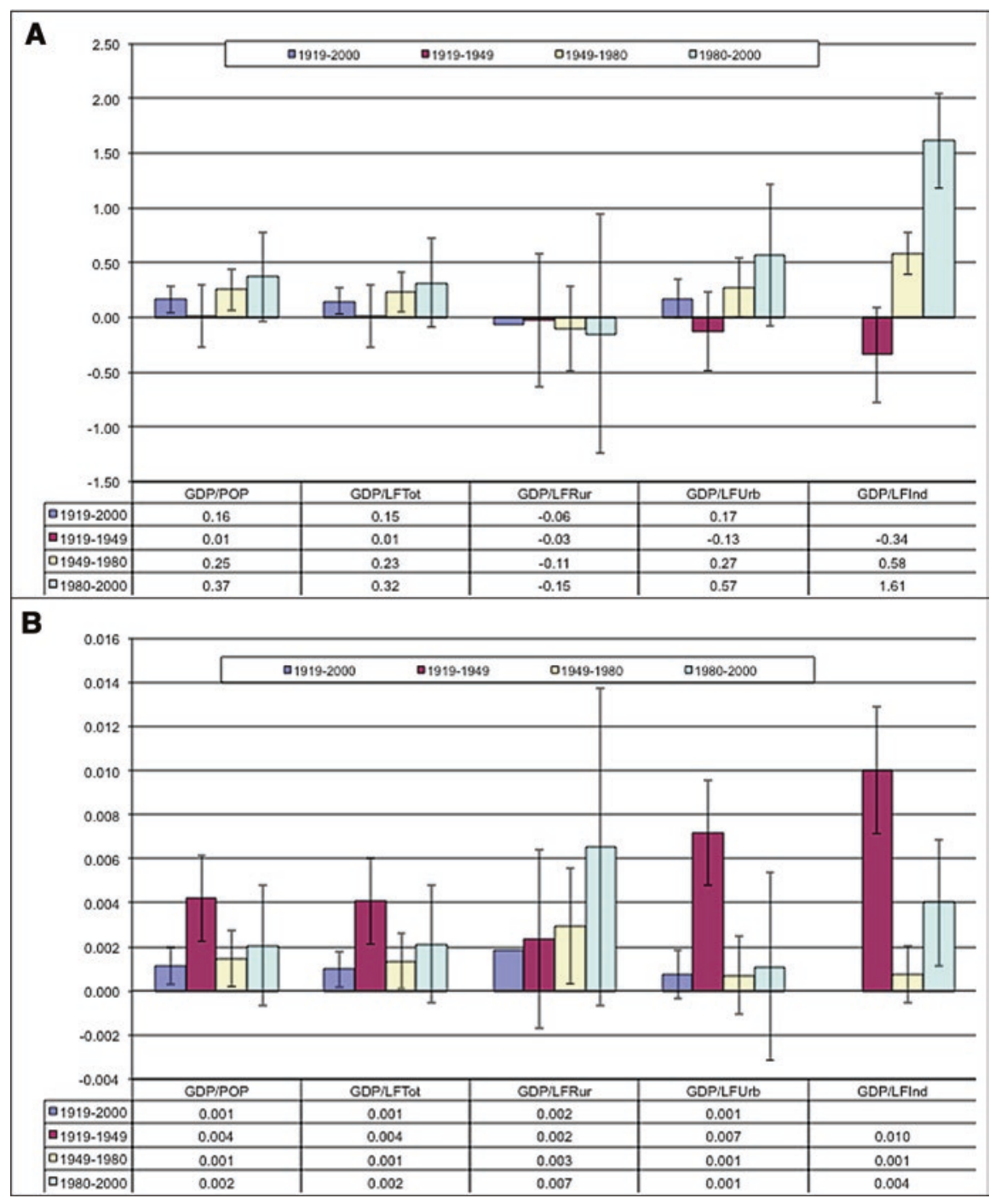

Fig. 3 Persistence in time of the effects of railroad stations in 1920 and the share of foreign-born population in 1920. (a) Impact of railroad stations in 1920 in the growth of income per capita (GDP/POP) and labor productivity (GDP/LF) in selected activities and periods (changing only the year of lagged dependence variable for each period; lines show 1 std-error). (b) Elasticity of foreign-born population in 1920 in the growth of income per capita (GDP/POP) and labor productivity (GDP/LF) in selected activities and periods (changing only the year of lagged dependence variable for each period; lines show 1 std-error) 
that phases of export-led growth were more dispersive than the import substitution phases; convergence was faster inside each region and thus regional disparities reinforced spatial inequalities in the country as a whole; and convergence of labor productivity was faster in urban activities than in rural activities.

More notably, estimated parameters show that conditions of access to infrastructure in 1920 - as proxied by the existence of railway station in the municipality were by far the most important factor conditioning the growth of Brazilian municipalities during the twentieth century. Other variables related to accessibility like the distance to the state capitals and the market potential of the municipality also played roles in the long-run growth of municipalities. This strong result corroborates the perception that Brazilian development strategies during the second half of twentieth century had misguidedly disregarded investment in transport infrastructure, particularly in railways, which as a consequence remains as a crucial hindrance to steady growth.

In contrast, institutional factors - as proxied by slavery (in 1872), education and human capital, political participation, and landownership concentration-did not play a significant role in long-run growth of income per capita or labor productivity of Brazilian municipalities. Even when jointly tested, their coefficients remained insignificant. The exception is the cultural and institutional innovations brought with the European immigrants as evinced by the share of foreign-born population in 1920 which shows a significant and positive effect on the secular rates of growth of both labor productivity and income per capita, specially in the agricultural activities.

Needless to say, the results are still preliminary and further extensions and scrutiny are required. A research priority, in this way, is the need of a more rigorous econometric treatment of the problems of endogeneity which affects the estimation of the coefficients of railroad station, foreign-born population, and slavery, among other variables.

A related priority is to undertake a panel data analysis including the inter-census periods from 1872 to 2010, thus allowing to circumvent some of the econometric problems and, consequently, to estimate in more rigorous way the interplay between factors conditioning the growth of Brazilian municipalities in the diverse development phases, in particular to update the analyses for the period 2000-2010 to disentangle the role played by spatial inequalities in the recent redistributive process (Rodrigues-Silveira 2012; Hoffman 2013).

In this way the tasks ahead are to complete the historical database on the conditioning factors - in particular on demographic aspects related to migration and dependency ratio; urban and transportation infrastructure; education and human capital; political participation, etc. - for the periods from 1872 to 2010 .

Open Access This chapter is distributed under the terms of the Creative Commons Attribution 4.0 International License (http://creativecommons.org/licenses/by/4.0/), which permits use, duplication, adaptation, distribution and reproduction in any medium or format, as long as you give appropriate credit to the original author(s) and the source, a link is provided to the Creative Commons license and indicate if changes were made. 
The images or other third party material in this chapter are included in the work's Creative Commons license, unless indicated otherwise in the credit line; if such material is not included in the work's Creative Commons license and the respective action is not permitted by statutory regulation, users will need to obtain permission from the license holder to duplicate, adapt or reproduce the material.

\section{References}

Alesina, A., \& Giulano, P. (2013). Culture and institutions. NBER working paper series. Retrieved from http://www.nber.org/papers/w19750

Andersen, L. E., Granger, C. W. J., Reis, E. J., Weinhold, D., \& Wunder, S. (2002). The dynamics of deforestation and economic growth in the Brazilian Amazon. Cambridge: Cambridge University Press.

Arantes, N. E., \& Souza, P. I. M. (1993). Cultura da soja nos cerrados. Piracicaba: PotafosAssociação Brasileira para Pesquisa da Potassa e do Fosfato.

Arbia, G., Basile, R., \& Salvatore, M. (2002). Regional convergence in Italy 1951-1999: A spatial econometric perspective. ISAE, Istituto di studi e analisi economica.

Azzoni, C. R. (1997). Concentração regional e dispersão das rendas per capita estaduais: Análise a partir de séries históricas estaduais de PIB, 1939-1995. Estudos Economicos, 27(3), 341-393.

Azzoni, C. R. (1999). Personal income distribution within states and income inequality between states in Brazil: 1960, 70, 80 and 91. In G. Hewings, M. Son, M. Madden, \& Y. Kimura (Eds.), Understanding and interpreting economic structure (pp. 287-296). Berlin: Springer.

Azzoni, C. R., Menezes-Filho, N., Menezes, T. A., \& Silveira-Neto, R. (2000). Geography and income convergence among Brazilian states. Washington, DC: Inter-American Development Bank.

Barat, J. (1978). A evolução dos transportes no Brasil. Rio de Janeiro: IBGE.

Barro, R., \& Sala-i-Martin, X. (1995). Economic growth. New York: McGraw Hill.

Bell, S. (1998). Campanha gaúcha-A Brazilian ranching system. Stanford, CA: Stanford University Press.

Bergad, L. W. (1999). Slavery and the demographic and economic history of Minas Gerais, Brazil, 1720-1888. Cambridge: Cambridge University Press.

Bértola, L., Willebald, H., Castelnovo, A. C., \& Reis, E. (2006, August 21-25). An exploration of the distribution of income in Brazil, 1839-1939. Paper presented at the XIV International Economic History Congress, Helsinki, Finland.

Buescu, M. (1979). Brasil: Disparidades de renda no passado: subsídios para o estudo dos problemas brasileiros. Rio de Janeiro: APEC.

Cano, W. (1973). Economia do Ouro em Minas Gerais. Contexto, 7.

Cano, W. (1985). Padrões diferenciados das principais regiões cafeeiras. Revista Estudos Econômicos, 15(2), 291-306.

Cano, W. (1993). Raízes da Concentração Industrial em São Paulo (2nd ed.). Rio de Janeiro: DIFEL.

Cano, W. (1997). Concentração e Desconcentração Econômica Regional no Brasil: 1970/95. Economia e Sociedade, 8, 101-139.

Castro, N. de. (2002). Expansão Rodoviária e Desenvolvimento Agrícola dos Cerrados. Texto para Discussão. Nemesis. IPEA.

Castro, N. de. (2003). Logistic costs and Brazilian regional development.

de Andrade, M. C. (1973). A terra e o homem no nordeste. São Paulo: Brasiliense. 
de Barros, R. P., Mendonça, R., \& Camargo, J. M. (1995). Pobreza no Brasil: Quatro Questões Básicas. In R. Henriques (Ed.), Desigualdade e Pobreza no Brasil (pp. 15-44). Rio de Janeiro: IPEA.

de Castro, A. B. (1969). 7 Ensaios sobre a economia Brasileira (Vol. 1/2). Rio de Janeiro: Forense. de Matos, O. N. (1974). Café e Ferrovias (Vol. 2). São Paulo: Editora Alfa-Omega.

de Oliveira, F. (1977). A Economia da Dependência Imperfeita. Rio de Janeiro: Graal.

Denslow, D., Jr. (1977). As origens da desigualdade regional no Brasil. In F. R. Versiani \& J. R. M. de Barros (Eds.), Formação Econômica do Brasil. São Paulo: Saraiva.

Ellis, A., Jr. (1951). O café e a Paulistânia. São Paulo: Universidade de São Paulo.

Engerman, S. L., \& Sokoloff, K. L. (2012). Economic development in the Americas since 1500: Endowments and institutions. Cambridge, MA: Cambridge University Press.

Engerman, S. L., \& Sokoloff, K. L. (1997). Factor endowments, institutions, and differential paths of growth among new world economies: A view from economic historians of the United States. In S. Haber (Ed.), How Latin America fell behind. Stanford: Stanford University Press.

Felice, E. (2013). Regional income inequality in Italy in the long run (1871-2001). Patterns and determinants. Documents de treball, Universitat Autònoma de Barcelona, Unitat d'Història Econòmica, 2013_08.

Furtado, C. (1968). Formação econômica do Brasil (8th ed.). São Paulo: Companhia Editora Nacional.

Furtado, C. (1970). Formação Econômica da América Latina. Rio de Janeiro: Lia Editor.

Galvao, O. J. de A. (1999). Comercio interestadual por vias internas e integracao regional no Brasil: 1943-69. Revista-Brasileira-de-Economia, 53(4), 523-558.

Gasques, J. G., \& Yokomizo, C. (1985). Avaliação dos incentivos fiscais na Amazônia. Mimeo: Instituto de Planejamento Econômico e Social.

Goulart Filho, A., \& Queiroz, P. R. C. (Eds.). (2011). Transportes e formação econômica regional: Contribuições à história do transporte no Brasil. Dourados, MS: Editora UFGD.

Graham, D. H. (1972, December). Foreign migration and the question of labor supply in the early economic growth of Brazil. Paper presented at the Economic History Workshop.

Graham, D. H., \& de Hollanda, S. B. (1971). Migration, regional and urban growth and development in Brazil: A selective analysis of the historical record, 1872-1970 (Vol. 1). São Paulo: Instituto de Pesquisas Econômicas.

Helfand, S. M., \& Rezende, G. C. (1998). Mudanças na distribuição espacial da produção de grãos, aves e suínos no Brasil: O papel do centro-oeste. Rio de Janeiro: IPEA.

Hoffman, R. (2013). Transferências de renda e desigualdade no Brasil (1995-2011). In T. Campello \& M. C. Neri (Eds.), Programa Bolsa Família: Uma década de inclusão e cidadania (pp. 207 216). IPEA: Brasília.

Homma, A. K. (2003). História da agricultura na Amazônia: Da era pré-colombiana ao terceiro milênio. Brasília: Embrapa Informação Tecnológica.

Ipeadata. (2014). Base dados sobre a economia brasileira do IPEA. Brasilia: IPEA - Instituto de Pesquisa Econômica Aplicada. Retrieved from http://www.ipeadata.gov.br.

Lagerloef, N. P. (2004). Regional income gaps in the U.S.A. today-what can geography and slavery explain? Paper presented at the Society for Economic Dynamics Meeting Papers.

Lagerloef, N.-P. (2005). Geography, institutions, and growth: The United States as a microcosm. Toronto, ON: Department of Economics, York University.

Leff, N. H. (1972). Economic retardation in nineteenth-century Brazil. The Economic History

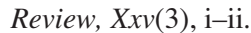

Leff, N. H. (1973). Tropical trade and development in the nineteenth century: The Brazilian experience. Journal of Political Economy, 81(3), 678-696.

Leff, N. H. (1991). Subdesenvolvimento e desenvolvimento no Brasil. Rio de Janeiro: Expressão e Cultura.

Libby, D. C. (1988). Transformação e trabalho em uma economia escravista: Minas Gerais no Século XIX. São Paulo: Editora Brasiliense.

Lima, J. H. (1981). Café e indústria em Minas Gerais, 1870-1920. Petrópolis: Vozes. 
Marcondes, R. L. (2005). Desigualdades regionais brasileiras: Comércio marítimo e posse de cativos na década de 1870. Tese de Livre-docência). Ribeirão Preto: Universidade de São Paulo.

Martins, R. B. (1983). A industria textil doméstica de Minas Gerais no Século XIX. Paper presented at the II Seminário sobre a economia mineira: história econômica de Minas Gerais e a economia mineira dos anos oitenta, Diamantina.

Martins, R. B. (2004). A historiografia sobre o Século XIX em Minas Gerais: notas para um debate. Paper presented at the Seminário Internacional sobre Historiografia de Minas Gerais, Instituto Cultural Amilcar Martins (ICAM). Belo Horizonte.

Milet, H. A. (1881). A lavoura da canna de assucar. Pernambuco: Typografia do Jornal de Recife.

Milliet, S. (1982). Roteiro do Café e Outros Ensaios. São Paulo: Editora Hucitec.

Nunn, N. (2007, November). Slavery, inequality and economic development in the Americas: An examination of the Engerman Sokoloff hypothesis, MPRA Paper No. 5869.

Oliveira, G. (2005). Juiz de Fora, Industrialização: Uma abordagem historiográfica. 1850-1930. In I Colóquio do Laboratório de História Econômica e Social da Universidade Federal de Juiz de Fora. Juiz de Fora: Editora da UFJF.

Pinto, A. A. (1903). História da Viação Pública de São Paulo (Basil). São Paulo: Typographia e Papelaria de Vanorden \& Cia.

Reis, E. (2014). Historical perspectives on regional income inequality in Brazil, 1872-2000. Working paper series (vol. 66). In Berlin research network on inequalities in Latin AmericadesiguALdades.net.

Reis, E. J., \& Blanco, F. A. (2000). Causes of Brazilian Amazon deforestation. In M. P. H. Vanhanen (Ed.), World forests: From deforestation to transition (pp. 143-165). London: Kluwer Academic Publishers.

Reis, E., \& Monasterio, L. M. (2010). Mudanças na concentração espacial das ocupações nas atividades manufatureiras do Brasil, 1872-1920. In T. R. Botelho \& M. H. D. van Leeuwen (Eds.), Desigualdade social na América do Sul: Perspectivas históricas (1st ed., pp. 243-274). Belo Horizonte, MG: Veredas e Cenários.

Reis, E., Tafner, P., Pimentel, M., Serra, R. V., Reiff, L. O., Magalhães, K., \& Medina, M. (2005). O PIB dos municípios brasileiros: Metodologia e estimativas, 1970-1996 (Texto para discussão). Rio de Janeiro: IPEA.

Reis, E. (2008). Income per capita of Brazilian municipalities in the 1870's. Rio de Janeiro: IPEA.

Reis, E. J., \& Margullis, S. (1990). Options for slowing Amazon jungle clearing. In R. Dornbusch \& J. M. Poterba (Eds.), Global warming: Economic policy responses (pp. 335-380). Cambridge, MA: The MIT Press.

Reis, E., Anderson, K., \& Speranza, J. (2007). The effects of climate change on the profitability and land use in Brazilian agriculture: A municipal cross-sectional analysis. Paper presented at the XV Congresso Brasileiro de Agrometeorologia, Aracaju, SE.

Reis, E., Blanco, F., Morandi, L., Medina, M., \& Abreu, M. (2002). O Século XX nas Contas Nacionais. In Estatísticas do Século XX. Rio de Janeiro: IBGE.

Reis, E., Pimentel, M., Alvarenga, A. I. M., \& Santos, M. C. H. (2011). Áreas mínimas comparáveis para os períodos intercensitários de 1872 a 2000. Paper presented at the I Simposio Brasileiro de Cartografia Histórica, Parati, RJ.

Restitutti, C. C. (2008). As fronteiras da província: rotas de comércio inter-provincial, Minas Gerais (1839-1884). Paper presented at the Simpósio de Pós- Graduação em História Econômica, Natal, RN.

Rodrigues-Silveira, R. (2012). Gobierno local y estado de bienestar: Regímenes y resultados de la política social en Brasil. Salamanca: Fundación Manuel Giménez Abad de Estudios Parlamentarios y del Estado Autonómico.

Santos, R. (1980). História Econômica da Amazônia. São Paulo: TAQ.

Silva, M. M. F. (1949). Geografia dos transportes no Brasil. Rio de Janeiro: IBGE-Instituto Brasileiro de Geografia e Estatística.

Silveira, P. (1957). A nova capital. Goiânia: Pongetti.

Stein, S. J. (1957). Vassouras: A Brazilian Coffee County, 1850-1900. Cambridge: Harvard University Press. 
Summerhill, W. R. (1997). Railroads and the Brazilian economy before 1914. Business and Economic History, 26(2), 318-322.

Summerhill, W. R. (2003). Order against progress. Stanford, CA: Stanford University Press.

Trew, A. (2014). Spatial takeoff in the first industrial revolution. CDMA working paper series, University of St. Andrews - Center for Dynamic Macroeconomic Analysis.

Versiani, F. R. (1993). Imigrantes, trabalho qualificado e industrialização, Rio e São Paulo no início do Século. Paper presented at the Encontro Anual da Anpec.

Weinhold, D., \& Reis, E. J. (2008). Land use and transportation costs in the Brazilian Amazon. Global Environmental Change, 18(1), 54-68.

Weinstein, B. (1983). The Amazon rubber boom 1850-1920. Stanford, CA: Stanford University Press. 